\title{
ANIMALS IN THE TRADITIONAL WORLDVIEW OF THE YORÙBÁ
}

\section{Ajibade George Olusola}

\begin{abstract}
This is a contribution to an on-going debate on animal ethics. It is an epistemological study into the Yorùbá beliefs and perceptions about animals that have existed and still exist in the areas they inhabit. The research sets out to elucidate the Yorùbá perception of animals with regard to their classification, habitat, and their role and position in religious, political, social, economic, and domestic domains of humans. This leads to an appraisal of relationships that exist between the Yorùbá people and animals in their communities. The study explores the Yorùbá folklore in its various dimensions as the paradigm to espouse their ontological perception of animals. The study concludes that the Yorùbá people attach much importance to their animals and that animals occupy an important place and space in human existence and life on the globe.
\end{abstract}

Keywords: African folklore, belief, classification of animals, human-animal relationship, taboo, Yorùbá

\section{INTRODUCTION}

The role of folklore cannot be overemphasised in any culture. It deals with any aspect of a culture's beliefs, practices, crafts, speech, legends, or stories that have been passed on orally from generation to generation (Quinn 2000: 129). Armstrong et al. (2003: 1-11) have given a laudable sketch of how animal ethics developed and its current status. It is believed that it originated among hunter-gatherers and it has grown to the extent of recognising freedom of life and existence for the animals that are also called "speciesism" in the language of Ryder. The debate on animal ethics is very interesting and timely; and it is worthwhile to include the views of people from other continents in the debate especially in this age of globalisation in which the world is practically conceived as a global village. The idea and attitude of the Yorùbá people towards animals need to be appraised as a form of exposition towards the policies on animals that may arise in a country like Nigeria in the nearest future. This paper begins with a classification of animals among the Yorùbá and the rationale behind these classifications ${ }^{1}$, and goes on to espouse animal-related taboos and some mythical allusions about them. It 
explicates the features and attitudes that demonstrate the equality of humans and animals.

\section{CLASSIFICATION OF ANIMALS AMONG THE YORÙBÁ}

There are various parameters for the classification of animals among the Yorùbá. One of the yardsticks is their groups. This is what the Yorùbá call òwó. There is even a proverb among the people that says Àikówòórìn ejò níi sekú pa wón lókòòkan 'Snakes are easily killed one by one because of their failure to operate as a group'. This proverb suggests that animals have their kingdoms and groups. It also connotes that if they move as a group, their vulnerability will be minimal. Another trait which they use in their classification is their habitat. That is why it is possible to talk about eran omi 'water animals, aquatic animals'; eran ilè 'land animals'. Physiological traits are also adopted to classify them. Thus, we have eran abiwo 'animals with horn', eran afayàfà 'reptiles', eran elésè méjì 'bipeds', elésè mérin 'quadrupeds', eye 'birds', eku 'rats'. A more general classification depends on whether the animal is domesticated or found in wild nature either in water or on land. This classification has given us eran ilé 'domestic animals' and eran ìgé 'wild animals'. This wider classification tallies with their perception of their world as a world of binary complementarities in which they see everything existing in the cosmology in dual form but not opposing each other. They categorise animals into three groups by using physiognomy as the parameter. This has to do with furry animals among whom lion acts as their king; animals with feathers have ostrich as their king, and the Squamate, the majority of which are reptiles, have python as their king. A close observation of the classification shows that the categories might easily overlap.

\section{ANIMAL-RELATED TABOOS AND MYTHICAL ALLUSIONS AMONG THE YORÙBÁ}

Among the Yorùbá, there are many taboos and myths about different types of animals, representing relationships that exist between the people and the animals and the Yorùbá philosophy about these particular animals. The Yorùbá have resolved to certain acts and 
responded to some animal species due to the interactions they have had with them over the time. These have entered into the canons of folklore in the form of mythical narratives, legends, poetry and even literature. Among such rules are, for example, the taboo of killing a mating animal. The Yorùbá explain this restriction by drawing parallels with the sexual relationship between humans, which should also never be disturbed. This is an indication of moral concern for the animals, which is a rather logical idea.

One must also believe that the feelings of others warrant our attention. For most people, the mere realization that others experience negative feelings in the same way that they themselves do is enough to generate a moral concern. The attribution of mental states, especially those associated with pleasure and pain, joy and misery, is connected irrevocably with the possibility of morality (Rollin 2003: 89).

This is to show that the Yorùbá believe that animals like humans are able to feel pain, pleasure, joy, fear, and so on. That is why this kind of taboo is strictly adhered to especially by the hunters, and a violation of the taboo may turn against them, i.e. they may have a similar experience when they are with their wives. This illustrates the belief of the Yorùbá that animals are divine just like humans and that the divine essence in them must be revered and honoured. Likewise, some animals are regarded as sacred and can neither be killed nor eaten. These include the vulture and ground hornbill. ${ }^{2}$ The parrot is also regarded as a sacred bird among the Yorùbá; they do not kill it but try to domesticate it. In ritual performance, only a feather of the parrot is used, which the Yorùbá believe to be possessed. The devotees of the deity Oya consider it a taboo to eat the buffalo. This deity is believed to be the mother of all buffalos. According to a myth, a hunter once went into the bush to hunt and as he was laying in ambush for animals on a tree he saw a buffalo next to a termites' nest. As he was getting ready to shoot the buffalo, he saw that the buffalo turned into a beautiful woman, who put clothes on and hid its skin inside the termites' nest. The hunter was astonished and could not do anything until the animal-woman left the spot. Later on, the hunter came down from the tree, took the skin from the termite nest and climbed up the same tree to lye in ambush again. Later on, the animal-woman came and wanted to take 
the skin so that she could transform into a buffalo again but the skin was gone. She searched for it and all her efforts were in vain. Then the hunter came down and approached the animal-woman and asked what she was searching for. The woman answered and the hunter told her that he would show her where the skin was only if the woman consented to become his wife. The woman agreed to the proposal after a long persuasion that her secret would not be revealed to anybody. This was how they entered into marriage. When the hunter returned home she introduced the new wife to the former housewife without revealing the secret of the new wife. They went on with their lives and the wife had three children with the hunter. Over the years, the senior wife became curious as to the identity of the strange wife but the husband refused to reveal it until one day which he was enticed with delicacies by this senior wife, and told her the secret and where he kept her buffalo skin. She was warned by the husband not to divulge the information to anyone, or he risked dying. That was how they continued their life in that village. One day, the hunter went to the farm with one of his children with the animal-woman and the rest of them stayed home with their mother and with the senior wife and her children. There was a quarrel between the two wives and the senior wife then used the secret of the skin to abuse the junior wife. She said, Máa je máa mu, àwò re $n$ be lákàá 'Eat and drink, your skin is inside the barn'. The junior wife was surprised to hear this and it greatly disturbed her. She felt that almost everybody in the village must have known her secret. The abuse revealed her where the hunter kept the skin. She took it and turned into a buffalo again, and so did her children, and they headed towards the farm where the hunter had gone with the other child. By the time the strange buffalos arrived at the farm the hunter already knew that there was a problem. He armed himself and the child and prepared for the battle. The buffalo (his wife who had turned into an animal) reminded the hunter of their bond and that the bond was broken by the hunter. The latter asked for forgiveness but it was all in vain. They started to fight and in the end, when the father was killed by the mysterious buffalo, the child ran home. As the boy was running away he was told by the buffalo that he and his generation must continue to worship buffalo. The buffalo went into the bush and left one horn on the ground for the boy as the idol to be worshipped. The boy was unable to turn into a buffalo because of the medicine that the hunter used on him. This was how the wor- 
ship of Oya started among the Yorùbá, and it is still conducted today. Buffalo's horn is usually one of the idols of this deity, and it is kept inside her calabash. There are salient aspects in the above myth with regard to animal ethics. Both animals and human beings have a god-given power to exert authority and influence over one another. Oya, who is a prominent goddess among the Yorùbá, has her origin in the animal kingdom. The type of relationship that exists between the Yorùbá hunter and the animal is also mysterious. If a myth like this should hold water then the Yorùbá must give more regard and honour to the animals. The Yorùbá believe that a human spirit may inhabit some animals, insects, or birds, such as, for example, cats, goats, deer, grass hoppers, bush rodents and some birds. ${ }^{3}$ This happens at the metaphysical level, and with the incursion of foreign religions - Islam and Christianity -, and global civilisation has not succeeded in destroying this belief, but has established this belief system instead. In most cases these human animals use the shape of animals to perpetrate evil deeds, though sometimes humans use the shape of animals to save their lives, especially during wars.

\section{ANIMALS AS EQUAL WITH HUMANS}

There are many traditions among the Yorùbá that demonstrate the equality of animals and humans. To begin with, in the past and even now in some rural areas populated by the Yorùbá, various animals are still sacrificed to the deities associated with these animals, and human sacrifice was also performed. This may not be common in contemporary society because of the fundamental human rights enshrined in national constitutions. Therefore, if both animals and humans can be used as objects of sacrifice, it is an indication that animals and humans are equal. Another point of emphasis with regards to the equality of animals and humans among the Yorùbá is a deep interaction between them, this applies particularly to domestic animals. Among the Yorùbá, children must be given names that have meaning, and the meanings have to do with the situation or circumstances surrounding the birth of their children. The Yorùbá people still actively observe the tradition of giving meaningful names also to their domestic animals. These names are not only meaningful but they represent the Yorùbá worldview. It is a common prac- 
tice among them, particularly in respect of dogs. Here are few examples of names given to dogs:

Ėyinlàárò - "We must think of the end of a matter". This is just telling them that it is not good enough to think of the present situation whenever a decision has to be made concerning a matter, but that there is also a need to think very carefully so that such a person will not have to regret the decision in the end.

Tantólóun? - "Who is as big as God?" This name which they sometimes give to their dogs represents the belief system of the Yorùbá people as an ethnic group who value the existence, power and prowess of the Supreme God in their daily activities. Since their dogs are their companions on most occasions, calling the dog by this name makes them conscious of their fate and faith in this God, and it also reminds them of His divine omnipresence.

Tanmèyinòla? - "Who knows the future?" This is another name that shows the weakness of humans with regard to what will happen to them in the future. The Yorùbá believe that noone knows future events except the Supreme God who is omniscient. This is why such a name is given to a dog, which is always by their side, as a reminder at all times.

Béèyànòkú - "If there is life". This name that the Yorùbá people sometimes give to dogs is the first part of a proverb which concludes with ise ò tán 'there is hope'. This name is an expression of their philosophical concept of vitality. They believe that anything can be solved unless somebody is dead; this is why they continue to hope and aspire towards something good and pleasant regardless of an unfavourable situation and circumstances. It is to remind people who are losing hope that they must remain hopeful so that they could see the light at the end of the tunnel.

Sometimes, the Yorùbá do give names to animals according to the colour of their skin; the white ones are called Afún 'white', the black ones are called Adú 'black', while the yellow ones are called Apón 'yellow'. Curiously enough, some people are called Adú, as well. All these above examples point to the fact that the Yorùbá believe that animals and humans share certain qualities. 
The Yorùbá attach great importance to oríkì, the laudatory/descriptive poetry of the Yorùbá. So they have personal oríkì addressed to individuals and they also have lineage or clan oríkì panegyric. ${ }^{4} \mathrm{~A}$ close observation of the Yorùbá people reveals that they also create oríkì for their animals. There are numerous examples of animal panegyric in the tradition, and some are included below. The first one is about antelope, which they call Etu. The praise poem goes thus:

Etu Òbèjé
Elésè osùn
Arítete-gbón-on-ni
Eranko tíi lé tìróò
Eranko tíi wa gònbò.

Antelope Òbèjé

The one who has legs painted red with camwood

The one who has thighs with which to touch the dew

The animal that put on eyelashes

The animal that wears gònbò tribal marks

The above antelope oríkì describes its appearance and manner. This is not in any way different from how the Yorùbá people formulate and chant the oríkìs about humans. It is a tradition of the Yorùbá people to wear tribal marks on their faces. This is what they now ascribe to the antelope because it has some natural marks on its face that look like tribal marks. In Yorùbá cosmography this stands for the equal importance of animals as well as humans.

Another animal that has been attributed oríkì is bush fowl, Àparò. The oríkì of the bird goes as follows:
Àparò
Bush fowl
Eni tí a ò fémo lówó rè
The one that we do not marry his daughter
Tó n gbàna lówó eni
And he is receiving dowry from us
Abi-tete-npológún erú
The one with thighs that are inviting the owner of twenty slaves
Abi-ìjánjá-pológbòn ìwòfà. The one with pieces of meat that are inviting the owner of thirty servants.

This oríkì about bush fowl also describes the attitude towards the bird in the farm and the sweetness of its meat. Bush fowl have the 
habit of going irresponsibly to any farm and freely plucking millet, corn, or any other edible farm product. This is why the bird is described as 'the one that we do not marry our daughter to but it is receiving dowry'. The dowry here is used metaphorically to symbolise whatever the bush fowl eats in the farm. The thighs and the pieces that are inviting the owners of twenty slaves and owners of thirty servants are also metaphorically used to mean important people in the society. This is just indicating the extent of the sweetness of its meat which everybody would like to eat. Linguistically, the etymological meaning of Àparò is the one that you kill and tell the news to others. The sweetness of its meat, after you have tasted it, will make you spread the news to other people. Also, the leopard or tiger Ekùn has its own panegyric among the Yorùbá. It goes as follows:

Ekùn, Ògíní omo İyáyò

Ekun Abijà̀wàrà

Eranko atoríméranje

Alábelówó.
Tiger, Ògíní offspring of Ìyáyò

Tiger who fights fiercely

The animal that eats flesh from the head

The one who has knife in its palm.

All attributes in the above oríkì of tiger praise its powers and heroic character. There are many animal lineages among the Yorùbá who are praised in a similar manner. If it is buffalo it is praised like this:
Efon Ògbó
Buffalo, Ògbó
Omo A-kù-má-rò
The offspring of the one who bleats as if it wants to rain

Gbogbo eni tí $n$ to Ekun léyìn

Everybody following buffalo

Ti Oya nín şe

Belongs to Oya

Òrò tí n lémo gungi ní wàràwàrà.

The spirit that pursues the child until he climbs the tree.

The above oríkì of buffalo is authenticating the above myth about it. Among the Yorùbá, the issue of beauty is of paramount importance. A beautiful girl is compared to Egbin, the gazelle, the animal which is considered the most beautiful. The beauty of this animal, Egbingazelle, is praised in the following oríkì: 
Egbin tó fi papa şelé

Ó fawo àrán şaşo àtésùn

Dáranijù

Eranko abarayòyò

Egbin dára títí

Elégàn Egbin kò sí nínú igbó.
Gazelle that uses grassland as its habitation

It uses velvet skin as its bed sheet Pretty in the forest

The animal that has a smooth body Gazelle is so beautiful

\section{bush}

Monkey Òbo is another animal which is considered worthy of dedicating an oríkì to, mainly because of its character and appearance, which closely resembles that of humans. The oríkì of this animal expresses the idea that it possesses many attributes that are similar to those of humans:

Òbo akájá lóde

A-gbórí-ití-pète-ìkà

A-gbórí-ití-pète-èké

Ògbójú Akítì tíi gbàbon lówó ode

The Monkey that teaches the dog how to hunt

The-one-who-schemes-evil-whileon-tendrils

The-one-who-schemes-lies-whileon-tendrils

The brave Akítì who seizes the gun from the hunter

Eranko tií tan ode wògbé sùàsùà.

The animal who lures the hunter into the thick forest.

The above oríkì characterises the relationship between the hunter and the monkey and the shared attributes between humans and animals. It shows that animals like humans are able to think and plan their activities in advance so that they would not fail. Another important issue discussed in this orikì is that the monkey is so wise and powerful that it may seize the gun from the hunter in the bush. It is the duty of the hunter who owns a dog to teach the dog how to hunt in the bush but we see from the oríkì that even a monkey can teach the dog how to hunt in the bush. This has to do with the skills and schemes of monkey in the bush. All the oríkìs praise the worth and the qualities in them that are similar to those of humans among the Yorùbá. 
The Yorùbá even compose songs which they sing to some domestic animals to portray their activities that are like those of human beings. Here is a folk song that they sing to a brave dog:
Ajá mi o!
Ajá ode
Ògémo-géréré
Ajá ode
Òsopàkà-gbemì
Ògbálè-gbaràwé

Ajá ode.

My dog!

The hunter's dog

The one that tears a child into pieces

The hunter's dog

The one that picks it and swallows

The one who sweeps the floor with leaves

The hunter's dog.

The relationship between the Yorùbá hunters and animals is very deep, complex and mysterious. Hunters believe that some animals are spirits, and that they transform into humans at nights when the hunters go to their hunting expeditions. Furthermore, they teach the hunters traditional Yorùbá folk medicine, which is, in turn, very useful to them and their society. Yorùbá hunters believe that not every animal that they encounter must be killed, because some of them are powerful and show their real colour during the night to the hunters.

On the other hand, the relationship between the Yorùbá hunters and the animal is characterised by enmity. Most animals flee from hunters because the latter are regarded as their archenemies. This unhealthy relationship between the hunters and the animals is described in the following hunting song:

Omo àlè lehoro nínú ìgbé o! Rabbit is a bastard in the bush

Omo àlè lehoro nínú ìgbé o! Rabbit is a bastard in the bush

Bó bá ti róde

Níó pale mó kíá

Whenever it sees the hunter

It will quickly take to its heels

Omo àlè lehoro nínú ìgbé o! Rabbit is a bastard in the bush!

This song represents the type of relationship that exists between the Yorùbá hunters and the animal, portraying the former as a threat to the latter. As rabbits are swift animals, hunters employ various schemes and tricks to kill them. But a proverb of the Yorùbá people shows that animals are also wise. The proverb says Àáyá gbón, 
Ògúngbè náà gbón; Àáyá n gungi, Ògúngbè náà $n$ bèrè 'The monkey is wise, and the hunter (Ògúngbè) is also wise; the monkey is climbing a tree and the hunter is also lying in ambush'. This scenario is that of a hide-and-seek interaction representing this unhealthy relationship between the Yorùbá hunters and the animal. It also demonstrates a fundamental point that like humans, animals also employ their senses, wisdom and intuition, and are able to escape dangerous situations.

Next to the names and the meaningful oríkì that the Yorùbá have dedicated to animals, there are various human activities that are ascribed to them, as they have been seen performing them. Àwòko, the nightingale, is regarded as the best singer. The Yorùbá have an adage about it - Àwòko ni olórí orin 'Nightingale is the best singer'. This proverb says that this bird is a perfect singer and that regardless of how well any human sings, he or she cannot be compared to the nightingale. In fact, many singers even liken themselves to nightingale in order to prove their mastery at the songs they sing. The Yorùbá people also like to know about future events, in order to find guidance in their activities. They observe the speech of a parrot - Ayékòótó (the name of which could be translated literally as 'people hate truth'), a mysterious bird which is regarded as important. They listen to the speech and are able to decode whatever it says because they know that this bird is possessed with the power of second sight. All the above examples and claims are evidences that both humans and animals are equal in the Yorùbá cosmology. ${ }^{5}$

People who keep domestic animals often tend to identify themselves with these. The Yorùbá proverbs say: Mo májá léyìn o jàn án nígi, èmi náà lo jàn nígi 'If you beat my dog which follows me with a rod, I am the one that you have beaten with the rod'. This demonstrates the Yorùbá view and beliefs about their domesticated animals. Some Yorùbá deities have their own dogs. For example, Lúbé is the name of Şàngó's dog, Mádìgbòlèsù is the name of Ėşù's (the trickster god) dog, Omidunsin is the name of Erinlè's (a river deity) dog. In Arà town, a community in the south-western part of Yorùbá land, dog worship is observed annually. This is in accordance with the role played by a dog in the creation myth or history of the town. Since then the dog has become a divine symbol for the people of Arà. Live dogs are not allowed in the town at all. It is probably the only Yorùbá 
town where no dog is to be seen (Beier 2000: 69-76). In fact, most Yorùbá folktales show deep relationships and interaction between the Yorùbá and their animals. ${ }^{6}$ Another folktale tells about İwò bird which took the baby of a woman who was bathing in the river. There are also tales about the interaction of a tortoise with the ruler of a town, when the townsfolk needed an elephant; also, the tale of Asín, the squirrel, and a man. The squirrel and Asín were fighting and the man was trying to come between them and Asín then bit the nose of the mediator. The above tales and many others show the interrelatedness of both humans and animals among the Yorùbá. It has been observed that some Yorùbá mourn the death of animals, while they consider them so dear and precious.

\section{THE ROLE OF ANIMALS IN THE LIFE OF THE YORÙBÁ}

In so many ways, animals occupy an important position in the existence of humans on the globe. It is a difficult task to enumerate the usefulness of animals to humans, especially to the Yorùbá. Even though many people claim that animals have a right to exist on their own without intrusion into their kingdoms, the truth is that among the Yorùbá it is believed that animals were created to serve humans. The Yorùbá use different types of animals, living in the sea and on the land alike, for food as they are regarded as a rich source of protein. It is the Yorùbá philosophy that animal meat is the carrier of food from the mouth to the oesophagus and finally to the stomach. Hence, they call animal meat Aláàárù - the Carrier. Some dishes are considered substandard and unpalatable without meat. They even believe that people who do not eat meat are eating àsán 'emptiness'. When their hunters go hunting in the bush they do everything possible to get game to have meat on their table. Whenever they are performing İjálá, Yorùbá hunters make fun of those who do not kill any animal when they go hunting. ${ }^{7}$ One of the chants they perform goes as follows:

Yó jòrúnlá láaságàn obè

Yó jòrúnlá láaságàn obè
He will eat his okra soup without meat

He will eat his okra soup without meat

Ode tó règbé o tí ò méran bò The hunter who has gone to hunt in 
Yó jòrúnlá láaságàn obè

the bush and did not bring animal He will eat his okra soup without meat.

This song among others is just an example of the importance that the Yorùbá people attach to animal protein. One of their proverbs even says Bíèrèké omo eranko kò bá bàjé, ti omo ènìyàn kò ní dùn 'If the cheek of offspring of an animal is not broken, that of the humans' offspring will not be sweet'. This adage points to the idea that even though the killing of animal for consumption is painful, it is necessary for human enjoyment and pleasure. Another related proverb says Ojú ni màlúù n ró, òbe ò dára lórùn 'The cow is suffering only during the time of slaughter, knife is not something pleasant on the neck'. This proverb agrees with the view that even though the Yorùbá are aware that animals have their own emotions and feelings, the necessity of self-satisfaction and pleasure compensates the killing of these animals for food. Also, another proverb says İfé tí a fé adie kò dénú, ibi kí á pa á je ló mo 'Our love for roosters is not genuine; the point is to kill them'. It means that even though people care and show affection towards animals, the ultimate purpose of an animal is to be served for food in the end. Illustrative of how the Yorùbá value animals and that they are aware of the vital roles that animals play in their lives, are the many ways in which they try to inculcate caring for the animals in their children from their childhood. This is done by means of folktales and moonlight poetry. ${ }^{8}$ Here is an example of a moonlight poem:

Adìe mi
Eyyi tí mo rà
Ó sì je lo
Lálé ojó kan
Ó kó sí kòtò
İyá bá mi gbé e
Gbígbé tí mo gbée
Gbígbòn ní n gbòn
Mo wá fi yéná

My rooster

The one that I bought

It went out

One night

It fell into a pit

Mother helped me carry it

As I carried it

It was shaking

I put it by the fire side for warmth.

This children's poem is like a religious didactic catechism, so that by the time the children become adults they know that animals should be cared for. This is to show that it is wrong to make a facile generalisation that the Yorùbá do not care for their animals, simply 
because they do not keep them as pets. Besides using animals for food, they are also used at sacrifices to the deities. The Yorùbá believe that proper sacrifice must be offered to the deities in order to avert calamities and to also propitiate the gods for their offences and mistakes that may incur the wrath of the deities upon them. This sacrifice may take different forms and shapes but the most important point is that many animals are used for sacrifice among the Yorùbá. The Yorùbá deities are numerous and each of them is associated with a particular animal, which is sacrificed to this particular deity. For example, Ògún (god of iron) is very fond of dogs, snails, tortoises and rams; Òsun (a goddess of the river called by that name) accepts goats and fowls; Èsù (the Yorùbá trickster deity) is fond of black fowl; Şàngó (god of thunder) is fond of ram; Òrúnmìlà (god of wisdom, knowledge and prophesy) is fond of rats and mud-fish; Obàtálá (the Supreme God) is fond of snails; Òsanyìn (the god of herbal medicine) is fond of tortoises; Egúngún (Masquerade) is fond of ram, just to mention a few. The Yorùbá know the choice of each deity and they do everything possible to meet their demands and needs so that things will augur well in their own communities. Also, animals occupy an important place in what will become of the human body after death within the Yorùbá cosmology. Some animals are used as components of rituals at the demise of old people among the Yorùbá. For example, whenever a hunter dies, it is considered necessary to find an animal that he used to kill the most during his lifetime and use it in the ritual. If this is not done, the hunter's soul cannot go to the place of happiness in heaven and at the same time his spirit will be troubling his fellow hunters and members of his family who are alive. ${ }^{9}$ Apart from the hunters' community, they usually kill a bird as an element for the ritual for any deceased person in a traditional Yorùbá society. The ritual sacrifice is called adì ìrànà 'the fowl that clears or buys the road'. Clearing or buying of the road here refers to the removal of everything that may hinder the hunter to move on to the life beyond. The road refers to the passage between the earth and heaven. This then connotes that without these animals as the ritual elements or objects of sacrifice, there will be no place for the hunters in heaven. Animals are even the consummators of various sacrifices and rituals that are addressed either to the deities or are performed for the purpose of traditional medicine. This is why these animals are eulogised: 
Bí a ò rígún

A ò gbodò şebo

Bí a ò rákàlà

A ò gbodò şorò
If we don't see the vulture

We must not offer sacrifice

If we don't see ground hornbill

We must not perform rituals.

In essence, the Yorùbá rely extensively on animals for their own well-being. Next to using the animals in various rituals and sacrifices, they also play a central role in Yorùbá traditional medicine. Medicines are made of a whole animal or part of it. There is a particular rat, called edá, which is used by folk healers to cure infertility because of its nature to reproduce within a very short time. Even being as small as it is, it brings much offspring. A part of the incantation goes Àbímolémo ni teku edá 'Edá rats procreate frequently'. This quality makes the rat an essential medicinal ingredient for infertile women to make them fertile. The issue of childbearing among the Yorùbá is a serious one and they do everything to make sure that a married woman bears children. They hold the belief that anyone without a child lives a meaningless life.

Animals are also partners in trade for the Yorùbá people. Prior to the period of the invention of motor vehicles and even after that, horse (Eşin) was used as a means of transportation. Dog is very useful as a guide and guard depending on its owner or user. The membranes of the traditional Yorùbá drums are made from animal fur. Hunters make use of dogs as partners in hunting and they serve as guards at home. It is also believed that they have the power of second sight to see impending doom; therefore they give signs to their masters while barking. This also signifies that they have emotions and are conscious of their environment. The issue of emotion and consciousness among animals has been a controversial one, though it has been said that

If, however consciousness is associated with reinforcement learning and the first conscious experiences that occurred on this planet were the basic ones of pains and pleasure, long before any concepts were thought of or any plans laid it for the future, then this does have implications for the way we see other species. It implies that emotional awareness is evolutionarily very old and possibly very widespread in the animal kingdom (Dawkins 2003: 99). 
This is an indication that if we believe that other living organisms, animals, to be specific, were created like their human counterparts, then they should be seen as having similar feelings and emotions with regards to various circumstances and situations. We must also be mindful of the treatment we give them, especially if we consider their usefulness and role in the survival of humankind on the globe.

\section{CONCLUSION}

This work discusses the beliefs and practices of the Yorùbá people in relation to animals. It shows their method of classifying the animals and the criteria the classification is based on. This article shows that the Yorùbá closely interact with animals, and this has also made their scientific understanding of animals around them. This deep understanding of theirs about animals has given them the power to know the attributes, characters and innate powers and virtues that the supreme God has given to various animals in the universe. This is also what they tap for their own benefit and advantage. Also, this has helped them to realise that the similar attributes and virtues that the supreme God has given to these animals can also be found among humans. This understanding helps them to conceptualise their world. The article shows that the Yorùbá people believe in the welfare of animals but not in the rights of animals. This is understandable because of the various functions they derive from their animals. The study also reveals that animals occupy an important sphere in the lives and existence of the Yorùbá people. They cannot do without animals in their religious, or social, economic and political life. In conclusion, the animal ethics in Nigeria certainly deserves rigorous and detailed research to encourage public awareness about what should be the right attitude of the people towards animals who are also God's creation.

\section{Comments}

${ }^{1}$ This classification may not correspond with the zoological classification but their classification has to do with their close observations and interaction with these animals in time and space. 
2 These animals are regarded as central in various sacrifices and rituals without which no sacrifice offered or rituals performed will be acceptable to the deities.

${ }^{3}$ It is a common belief among the Yorùbá that some people who have mystical powers use various types of animals to perform certain acts and behaviour. This group of people includes the witches, wizards and the spirit-children, called Emèrè.

${ }^{4}$ The Yorùbá hold the belief that every creature has oríkì and that the essence of any living being is manifest only or can only be explored by proper recitation of the oríkì. There are two types of oríkì - personal oríkì, and clan or lineage oríkì.

5 The Yorùbá believe that these animals have their own diviners and healers just like humans do.

${ }^{6}$ Babalola (1973) and Ojo (1973) have compiled some Yorùbá folktales. Their folktales reveal that there is a close and deep relationship and interaction between the animals and the Yorùbá. In all their folktales there are no limits to the interaction of man and animals. They do speak, eat and relate freely with each other without any barrier. This illustrates the Yorùbá worldview in relation to their animals.

7 İjálá is a popular oral genre of Yorùbá hunters. Its variant is called İrèmòjé. Both are enigmatic in meaning, and a rich source of oral repertoire of the Yorùbá philosophy about their cosmography.

${ }^{8}$ Moonlight poetry is an established folklore genre among the Yorùbá; its purpose is to teach the socio-cultural values and norms to the children. This will in turn form an integral part of their adult behaviour and the conceptualisation of their world and environment.

9 This ritual is called İpà among the Yorùbá hunters' community. It is a process in which all the hunting gear of the deceased hunter will be taken to the outskirts of the town to a spot chosen by divination. If this ritual is not performed, the deceased hunter cannot join the world of the Yorùbá ancestors.

\section{References}

Armstrong, Susan J. \& Botzler, Richard G. (eds.) 2003. The Animal Ethics Reader. London \& New York: Routledge.

Babalola, Adeboye. 1973a. Akojopo alo Ijapa, Apa Kiini. Ibadan: University Press Limited. 
Beier, Ulli. 2001. The Hunter Thinks the Monkey is not Wise - the monkey is wise, but he has his own logic: A selection of essays. Bayreuth African Studies Series, 59. Bayreuth: E. Breitinger.

Dawkins, Marian Stamp 2003. Animal Minds and Animal Emotions. Armstrong, Susan J. \& Botzler, Richard G. (eds.). The Animal Ethics Reader. London \& New York: Routledge, pp. 94-99.

Ojo, Olagoke 1973. Ijapa Tiroko Oko Yannibo:Awon itan aroso aladum fun eko ede ati idraraya. Ibidan: Longman Nigeria Limited.

Quinn, Edward 2000. A Dictionary of Literary and Thematic Terms. New York: Checkmark Books.

Rollin, Bernard E. 2003. Animal Pain. Armstrong, Susan J. \& Botzler, Richard G. (eds.). The Animal Ethics Reader. London \& New York: Routledge, pp. 86-91.

Ryder, Richard D. 1998. The Political Animal: The Conquest of Speciesism. Jefferson, N.C: McFarland. 